Revista Voluntas: estudos sobre Schopenhauer - 2ºmestre 2011 - Vol. 2 - No 2 - ISSN: 2179-3786 - pp. 03-30.

\title{
"What makes Human Beings into Moral Beings?"1 The Significance of Ethics in the Process of Evolution
}

\author{
Babette Babich ${ }^{2}$ \\ Professor of Fordham University, New York City, editor of New Nietzsche Studies \\ E-mail: babich@,fordham.edu
}

\begin{abstract}
Just as animals in general are described as "feeling" nothing like "pain" but "stimuli responses" or "behaviours," scientific theorists once proposed to reduce the differences between socio-cultural expressions of pain to differences in general between the races: Black, White, Asian, and especially so-called aboriginal peoples and Nazi experiments on human pain extended the same test of pain thresholds from experiments performed on animals for centuries (the same experiments on animals unchecked to this day) to human beings designated as subhuman. Ethological studies by Franz de Waal suggest that animals share this capacity for sympathizing with the other. Schopenhauer's notion of compassion thus serves as the basis for a new understanding of becoming moral. This essay situates Schopenhauer with respect to Kant as well as Nietszche and develops connections with Levinas and Adorno as well as Isaac Bashevis Singer.
\end{abstract}

KEY WORDS: Evolutionary ethics, animal empathy, Vivisection.

RESUMO: Apenas animais em geral são descritos como seres que não "sentem" nada semelhante a "dor", mas [sentem] somente "estimulo respostas" ou "comportamentos". Cientistas do passado propuseram reduzir as diferenças entre expressões socioculturais de dor para diferenças em geral entre as raças: Preto, Branco, Asiático, especialmente as então chamadas pessoas aborígenes, assim como os experimentos nazistas sobre a dor humana estenderam o mesmo teste de limiar da dor da realização de experimentos em animais por séculos (os mesmos experimentos sobre animais não fiscalizados até hoje) para seres humanos designados como sub-humanos. Estudos etológicos de Franz de Waal sugerem que animais compartilham esta capacidade de partilhar (sentimentos) com os outros. Deste modo, a noção de compaixão de Schopenhauer serve como base para uma nova compreensão do tornar-se moral. Este ensaio citua Schopenhauer em relação a Kant, tanto quanto Nietzsche e desenvolve conecções com Levinas, Adorno e Isaac Bashevis Singer.

PALAVRAS-CHAVE: Ética evolucionária, empatia animal, Vivisecção.

\footnotetext{
${ }^{1}$ The title of this essay was originally set for presentation at a 2007 conference on "Ethics in the Shadow of the Holocaust" to a forum of international students at the Technische Universität Ludwigshafen. Although the subtitle is my own, I approached the title and theme in the spirit of the dynamic dialectic of Schopenhauer's admirable prize essays. In advance it should be said that this essay pays homage to Schopenhauer's efforts without meaning to pretend to the same achievement.

2 Babette Babich is author of The Hallelujah Effect kd lang's Desire, Adorno's Ghosts, and Nietzsche's Beethoven (Aldershot, 2012); La fin de la pensée. Sur la différence et la politique de la désunion entre philosophie analytique et philosophie continentale (Paris, 2012); Nietzsches Wissenschaftsphilosophie (Oxford/Bern, 2010); $\Perp$ Eines Gottes Glück, voller Macht und Liebe« (Weimar, 2009); Words in Blood, Like Flowers (Albany, 2006); Nietzsche e la scienza (Milan, 1996); Nietzsche's Philosophy of Science (Albany, 1994). Professor Babich has also written on life-size bronzes in antiquity and she is deeply concerned about the exceedingly desperate plight of the whales (all species) as well as all other creatures, among others, leopards and lions, wolves, bears and foxes, song birds as well as birds of prey, the vanishing salamanders, bees, and trees.
} 
In the wake of the death of God, the reduction of ethics to biology is represented (on the pro-science side and this means on the side of analytic-style philosophizing), ${ }^{3}$ as a clarification of actions that are dubbed "moral.". These our actions, so scientific reductionism has been telling us since before Nietzsche's days, ought not to be counted as moral owing to our origination in the image and likeness of God and certainly not (although even Kant did not suppose this causality) because we follow the dictates of reason. Rather, so the evolutionary ethicists tell us, we are as "moral" as we are just because it is in our "genes," just to the extent that it serves our species' survival. This all-purpose account (all-purpose versatility is the great advantage of reductionism) thus serves to justify claims for intrinsic human kindness as well as for intrinsic human brutality. In the same fashion, the claims made for evolution as a basis for ethics are typically sweeping.

All philosophy, we are informed-rather in the manner in which Thrasymachus defined justice for Socrates as the interest of the dominant power - can henceforth be set on a new and biological basis: it turns out that we are ethical for the same reasons that we scratch: something itches or otherwise directly moves us to action and, sort of like the iPhone, there's a genetic program for that. And ever since evolutionary explanations have been propounded, proponents have been surprised, also not unlike Thrasymachus who after he had offered his definition of justice wondered, in seemingly feigned confusion, why Socrates did not simply "burst into applause," evolutionary ethicists often express a parallel surprise, like Stephen Hawking on the redundancy of philosophy as such from Wittgenstein to Dawkins and Dummett, wondering why philosophers do not simply end their debates, fold their tents, and slip away ${ }^{4}$.

\footnotetext{
${ }^{3}$ Analytic style philosophy does not refer to the analytic tradition, strictly supposed, and that is variously defined but the dominant modality of mainstream philosophy as opposed to continental style philosophy, which itself does not refer to the practice of philosophy on the European continent but to a tradition representative of the style of Nietzsche, Heidegger, Derrida, Deleuze, etc. The distinction is important to make to the extent that the continental tradition provides the best resources for reading Schopenhauer. For background, see BABICH, Babette. "On the Analytic-Continental Divide in Philosophy: Nietzsche's Lying Truth, Heidegger's Speaking Language, and Philosophy," In: PRADO, C. G., [Ed.], A House Divided: Comparing Analytic and Continental Philosophy (Amherst, NY: Humanity Books, 2003), pp. 63-103.

${ }^{4}$ I say this cavalierly but science has already used the tactic to close more than one philosophy department and it may well become a trend (that is, were a competent administrator keen on reducing costs to draw the conclusions that follow from the programme of eliminative materialism à la the Churchlands and others). Note that I here prescind from addressing the issue of the different approaches to philosophizing as these approaches tend to compound the difficulties I address here inasmuch as the most dominant trend in philosophy is pro-science to a scientistic fault. See my comments on this in a practical professional, i.e., academic context: ERWIN, Dennis; STORY, Matt (Babich interviewed). "An Impoverishment of Philosophy," Purlieu: Philosophy and the University (2011): 37-71.
} 
Science has spoken: there is no moral law, no meaning to the idea of moral worth. When philosophers for their part answer the enthusiasm of such biological claims by noting that this contention fails to tell us why such actions are moral, that is to say, that it fails to illuminate just what it is about such actions that makes them moral as such, as opposed to simply seeming to be moral, the scientists and scientistic ethicists roundly miss the point of the objection. The philosopher's protracted debates about what makes a moral action moral seem so much empty talk. The evolutionary ethicists blink (to use Nietzsche's word for uncurious incomprehension): as it transpires, they are not interested in learning the long history (or any segment of the history) of philosophical debate on the nature of ethics - on akrasia (knowing the good but doing what is wrong anyway, sometimes quite against one's "will") — or the telling of lies (lies for no reason vs. lies for convenience or to avoid embarrassment or else a lie to save a human life or even a dog's life) and so on.

In what follows, I discuss the case of recognizing oneself in a mirror as a test of reflexive awareness and the notion of empathy in order to consider Schopenhauer's claim to have uncovered the ultimate philosophical basis for morality in compassion. I conclude with a brief reading of Nietzsche's reflections on animal vivisection and the ultimate object of compassion.

\section{Mirrors and Monkeys: Self-Recognition and Empathy}

Apes fascinate us, to cite the helpful ambiguity of the title of Alison Joly's reviewer's remarks on Frans de Waal's edited book collection, Tree of Origin and his The Ape and the Sushi Master:. "That, there, is me,"6 referring as much to the phenomenon of the mirror, i.e., the grand achievement that we, narcissus-struck as we are by our own fascination with ourselves, take it to be to be able to recognize ourselves in a mirror or a photograph or video of ourselves, for it turns out that apes, like dolphins, like elephants (for all that this changes any bit of the way we treat them), do do both. Noting that primates have this in common with other animals as well also suggests, and this may be even more significant, that experiments to "test" this capacity are difficult to design. The recent

\footnotetext{
${ }^{5}$ WAAL, Frans de [Ed.]. Tree of Origin: What Primate Behaviour Can Tell Us about Human Social Evolution (Cambridge: Harvard University Press, 2001) and WAAL, Frans de. The Ape and the Sushi Master: Cultural Reflections by a Primatologist (London: June 2001).

${ }^{6}$ JOLY, Alison. “That, There Is Me,” London Review of Books, Vol. 23, No. 18 (20 September 2001): 11-12.
} 
publication of work on rats' capacity for empathy, showing at willingness to help free another rat by acting to help liberate a trapped cage-mate ${ }^{7}$ (and note that we regard ourselves as having empathy whether we act on behalf of another or not, an issue that is important when it comes to double-ethical bookkeeping across the species and sometimes across gender differences, across the races). Thus the experimental project in question, and there are several lines of work here as the literature cited points out, also offers an object and grim demonstration of the researchers' lack of feeling for or compassion for their subjects. Not incidentally so, but of necessity to the extent that research of this kind constitutes a scientific tradition that goes back to antiquity but received its fully modern contours in the vivisection of Claude Bernard. Science of this kind represents little more than so very many-staggeringly many_variations upon studies in cruelty. To be sure some seem more or less compassionate (especially those prepared for the public gaze) but it matters when it comes to science that anti-vivisectionist campaigns, themselves centuries old, have changed nearly nothing about the way science is done ${ }^{8}$.

Kittens find their first encounter with a mirror image fascinating but quickly learn to look elsewhere, researchers have accordingly drawn the conclusion that the kitten does not recognize itself, but it may be that the kitten does indeed recognize itself and is, for exactly this reason, uninterested. Perhaps the kitten in the mirror is a playmate, ah no, that, there is me-meaning, no more than, meaning, only me. One could wonder if perhaps the sovereign disinterest in one's appearance might well be an emblem of what Nietzsche called active or noble - or self-referred - morality, the morality of a born predator, whereas we, by contrast, are very interested in our mirror images just because we, all of us slavely moral, are extremely anxious about the perceptions others have of us; our morality is not active but reactive, other-directed morality. We wonder about our attractiveness, yes/no, about the evidence of last night's party, the healing of a scar, and so on. This requires that we distinguish ourselves as ourselves, identify ourselves with our image of our mirror

\footnotetext{
${ }^{7}$ BARTAL, Inbal Ben-Ami; DECETY, Jean; MASON, Peggy. "Empathy and Pro-Social Behavior in Rats," Science, Vol. 334, No. 6061 (9 December 2011): 1427-1430.

${ }^{8}$ See ROBERTS, Catherine. Science, Animals, and Evolution: Reflections on Some Unrealized Potentials of Biology and Medicine (Westport, CT: Greenwood, 1980). For a globally political and sociologically attuned discussion of the epistemological implications of this kind of experimentation on both animals and human beings, see VISVANATHAN, Shiv. "On the Annals of the Laboratory State," In: NANDY, Ashis [Ed.] Science, Hegemony, and Violence: A Requiem for Modernity (Oxford: Oxford University Press, 1988), pp. 257-288.
} 
image (and what it should be) and this is not irrelevant to a certain claim of consciousness, self-consciousness. But and once again, it turns out that we share this ability (this self-interested self-awareness) not only with monkeys and apes but also with elephants and dolphins and whales, which we have only recently learned-it turns out that it is no easy trick to get the mirror right, elephants need a full size mirror (and this is similar to the claims made some years ago that newborn infants simply cannot focus their eyes, like kittens who are born blind, but it turns out they can focus provided one attends to a depth of field of 12 inches or so, the distance from the child at the mother's breast to the mother's face).

Beyond the achievement that it is - think only of Jacques Lacan - to recognize oneself in a mirror, there is the even more conscious and conscientious case of rats and mice who seem aware of - and unwilling to cause - the pain of others, in experiments demonstrating that rats and monkeys refuse to press a lever for food when doing so is to deliver a shock to another animal, one rhesus monkey, in particular, refusing to do so for an astonishing twelve days.

De Waal cites monkeys and their reticence to injure others, or rats that press a lever not for food but to lower a rat suspended and struggling in a harness (dismayed by such a display of seeming empathy, researchers suggest that the cries of the suspended rat "disturbed" the other), ascertained by human animals who, of course, set up the experiment in the first place, just to see what the animals might do. These experiments go back more than fifty years, and older observations offer further attestation that seeing an animal in distress can inhibit an action, even an action that brings a reward. Milgram's experiments show that higher primates like ourselves can be induced to bypass this same resistance, and a reflection on the moral willingness to allow acts of cruelty (as in Milgram's case, even simulated acts) or indeed to set up the apparatus that delivers acts of cruelty, such as shocks to rats or monkeys suggest that human beings can be distinguished less in terms of the ability to draw rational inferences or in terms of their moral capacities but sheer malice aforethought and callous indifference to the pain and suffering such experiments deliberately, repeatedly induce.

All of science, especially biological science, is and has ever been soaked in the blood and suffering of those other than the researcher, mostly animals but not only, and the 
scientist, as the Milgram experiments illustrate, and this is why they are so chilling, turns out to be happy to experiment on human beings when the opportunity presents itself. Here if there were enough time we could consider the practice of medical science in Nazi Germany but not just in Germany but in racist and white America, not only years ago, but recently, as against blacks, as against native American Indians and others ${ }^{9}$.

We know insensitivity to animal distress to be true of workers in their relationships with the animals raised for food at factory dairies and factory farms and we know this to be still more characteristic of the truckers who transport chickens and ducks, pigs and cattle, horses and sheep, and so on: taking them to their doom, less with efficiency than lack of concern, seemingly treating them as if they were, as they might as well be, "dead" already ${ }^{10}$. They are bound for the stockyard, why not treat them like any other kind of cargo, why give them food or water, why protect them from rain and cold? Or of workers at feedlots or even still and even worse in the stockyards after sale where animals wait for death, packed with thousands of others, standing deep in excrement, nearly always without food and water or slaughterhouse workers and butchers who process - this number is already outdated and the real number is still higher-that is to say, who slaughter some twenty-five million animals a day in the United States alone ${ }^{11}$. All these are, we think, fairly low-level jobs, banausic in the extreme. Such low-level workers 'disattend' to the suffering

\footnotetext{
${ }^{9}$ It is worth reading Ludwik Fleck's Genesis and Development of a Scientific Fact, Fred Bradley and Thaddeus Trenn, trans. (Chicago: University of Chicago Press 1979) not only owing to the introduction provided by Thomas S. Kuhn, who "borrowed" rather a good deal from Fleck for his The Structure of Scientific Revolutions, it and for many other reasons that repay study but also because of its discussion of the Tuskegee experiments on deliberately inducing syphilis in black males. See further, JONES, James H. Bad Blood: The Tuskegee Syphilis Experiment-A Tragedy of Race and Medicine (New York: Free Press, 1982 edition) as well as, more recently, and more popularly WASHINGTON, Harriet. Medical Apartheid: The Dark History of Medical Experimentation on Black Americans from Colonial Times to the Present (New York: Anchor, 2008) as well as REVERBY, Susan M. Examining Tuskegee: The Infamous Syphilis Study and Its Legacy (The University of North Carolina Press, 2009).

${ }^{10}$ The subtitle of Gail Eisnitz's still unbettered research study, EISNITZ, Gail. Slaughterhouse: The Shocking Story of Greed, Neglect and Inhumane Treatment Inside the U.S. Meat Industry (Amherst, NY: Prometheus, 1997), is probably the most important to parse in this context. See too MARKUS, Erik. Meat Market: Animals, Ethics, and Money (Brio Press, 2005) as well as KRIMSKY, Sheldon. Science in the Private Interest (Lanham. MD: Rowman and Littlefield, 2003). This point, as I have shown elsewhere in specific connection with Adorno, corresponds to the subtext of Heidegger's infamous comment regarding the industrialization of agriculture and the manufacture of corpses. See BABETTE, Babich. "Adorno on Science and Nihilism, Animals, and Jews." Symposium: Canadian Journal of Continental Philosophy/Revue canadienne de philosophie continentale, Vol. 14, $\mathrm{N}^{\circ}$ 1, (2011): 110-145.

See very practically too the various contributions to IMHOFF, Daniel [Ed.]. CAFO: The Tragedy of Industrial Animal Factories (Earth Aware Editions, 2010).

11 WARRICK, Joby. "They Die Piece by Piece". In: "Overtaxed Plants, Humane Treatment of Cattle Is Often a Battle Lost" Washington Post, Apr 10, 2001.
} 
they cause, as do the Canadian and Scandinavian fishermen who club baby seals to death and indeed, this is a phenomenon characteristic of violence tend to be more (not less) brutal and insensitive in what they do and their manner of doing it, some develop, more than a few evidently, a certain aggressive sadism towards the animals ${ }^{12}$. But the same callous insensitivity also is characteristic of the scientist, the physical anthropologist, the biologist, and indeed the medical researcher even when it comes to human health research. Thus the insensitivity in question is not linked to vulgar, course occupations. The triumphant ideal of the research scientist presupposes and so requires the same disattending, which we speak of as so much "objectivity," all practiced for the greater good of humanity, a good that is sometimes proclaimed as including the benefit of the animals in question, who are sometimes represented as willingly "giving" their lives for this end.

Are we not we in danger of projecting human qualities into animals by saying that they suffer? They are only animals, after all. So goes the circular argument used to justify our callous treatment of animals by advocating yet more callousness under the officious rubric of scientific objectivity. They can't feel pain after all,- - and centuries of dispute on other minds come home to roost here, we really can't be "sure" that they do-and we cannot know if they have any conscious awareness at all (this Cartesian idiocy continues in the face of every demonstration to the contrary). Thus, so Descartes argues, like the machines that he knows them to be, 'unconscious,' and hence putatively insensate, beasts manage to eat and defend themselves by means of "mechanism," a mechanism evolutionary biologists (which would be the new name for what used to be called sociobiologists) would be quite politely and often with a joking sensibility to cover a very serious contention, serious because it animates the working industry that science happens to be (science is a business after all) be quite willing to extend to our conception of the human.

Rather than reducing ethics or morality to biology, i.e., claiming that the moral is the biological, I am prepared to argue that ethical behaviour and/or action as well as moral feeling or sentiment is not limited to humanity alone but can be found throughout the world of sentient beings. The ethologist noted above, Frans de Waal has been investigating empathy in primates and his work among the findings of many others would seem to

${ }_{12}$ See again, Eisnitz, Slaughterhouse as well as the discussion and review of Eisnitz' study in SCULLY, Matthew. Dominion: The Power of Man, the Suffering of Animals, and the Call to Mercy (New York: St. Martin's Press, 2002). 
support such a claim. It is essential to note that inasmuch as de Waal speaks of empathy and not "empathy-behaviour" (he has already made enormous strides in the field of animal behavior which usually describes everything animals do as so many behaviours, whereby the language of mere "behaviour" becomes a rhetorical device for supposing that the language of behavior is somehow objective, underlining the prohibition against anthropomorphism, which is of course an effective way to assure certain conclusions).

The caveat against anthropomorphism is thus well-established if it is also true, as Schopenhauer argues that it serves to guard certain very theologically oriented metaphysical privileges. Behind our sober anxiety concerning the viability of anthropomorphic projections, we need to keep ourselves very distinct from animals. This is also to say that even in the absence of an active belief in God, we still want to imagine ourselves as imago dei. We cannot tolerate the notion, and even evolutionary biologists are not quite prepared to claim, that we are no different from animals. Let the primatologists tell us about our nearest primate relatives, citing morphological and now genetic evidence to justify the claim of a plain biological relation or similarity but heaven forbid that a scientist use the same illustration to claim that we are the same, worse yet to claim that animals might be the "same" or even similar to us.

After more than a century and a half after Darwin, that is, even after regarding ourselves as scientifically rational and enlightened (and that perspective on ourselves spans millennia) we remain deeply anxious about being lumped in with so-called "other" animals. For Nietzsche, if the moral superiority of Christianity had clearly triumphed over "the morality" of the ancient world (and this ancient world would be not only the worlds of Aristotle's Athens and Stoic Rome but also the heroic world of the Northern European and the Celtic sagas, as Alasdair MacIntyre's After Virtue illustrates this complex conjunction), Christianity itself was on the decline, a decline which did not correspond to a true Renaissance of classical or antique ideals of virtue. Hardly a return to ancient ideals, "modern human beings live," for Nietzsche, "in this vacillation between Christianity and antiquity, between an intimidated or hypocritical Christian morality and an equally cowardly and inherited turn to antiquity...” (SE §2).

But the problem is not Christianity or religion per se. Much rather the problem is nothing less than modern science. Thus in On the Genealogy of Morals, Nietzsche argues 
that so far from being a liberating or genuine enlightenment ideal, science is the newestthe latest and the best - instauration of the ascetic ideal (GM III), whereby all forms of the ascetic ideal turn out to be anti-ethical, providing one understands the ideal of an ethos of excellence or strength (a notion related to Nietzsche's pessimism of strength), coexisting with or substituting for (for Nietzsche, there would be no difference) moral ways of life. Here it will not be a matter of the virtue that is attained by active doing, by the practice or virtuousity of a way of life, or an ethos. Instead what is at stake is character and the achievement of the ascetic ideal is a "given" (almost everyone in the natural history of the ascetic ideal of cultivated or secured weakness is a Calvinist or on their way to Calvinism). Thus Schopenhauer invokes the scholastic expression operari sequitur esse [what we do follows from what we are] — a perspective on being that Sartre would invert or better said: convert into existentialism but which is indeed already at work in Schopenhauer and in Nietzsche, and it is this that makes us "interesting," to use Nietzsche's ambivalent term in the Genealogy. Expressed in Pindar's encomium to achieved or perfected excellence, this same ideal urges us to realize or accomplish or perfect ourselves: to become the one you are, a naturing of one's first nature as a nature apt or able to acquire such perfections involves Aristotle's ethical evolution or fashioning of character as a second nature. To explain this scholastic maxim, Schopenhauer writes, "everything in the world operates in accordance with what it is, with its character and quality, in which all its manifestations are therefore already contained potentially." "As a man is, so he is bound to act." 14 We remain even to this day very committed to this way of thinking as current research on the brain as indeed into the genetic basis of human behavior shows.

Schopenhauer expresses the key question of morality in a world of evolution and natural selection. For the point of evolution and natural selection is not about qualitative achievement but reproductive excellence. The Victorians who thought so in their reception of Darwin missed the point. As it happens, all that matters for evolutionary success is reproductive success or survival, not qualitative excellence. The wolves that once flourished in Europe, the Eastern cougars that once lived in the current regions of New York City, have been driven out by human beings in simple effect, and not because we

13 SCHOPENHAUER, Arthur. On the Basis of Morality, trans. E.F. J. Payne (Providence/Oxford: Berghahn Books, 1995 [1965]), p. 111. Über die Grundlage der Moral, In: Schopenhauer, Werke in Einem Bande (Munich: Hanser, 1977).

14 SCHOPENHAUER, Arthur. On the Basis of Morality, p. 112. 
humans are better or more excellent or more beautiful life-forms. Rather it is because of human selfishness: behind all our talk of conservation, betrayed in the contradictory notion of sustainable development, ${ }^{15}$ we desperately do not want to share the world with non-human animals. Thus the living spaces on the face of the earth that still remain are living spaces already earmarked for future human habitation or us, be it for development or be it for the notion of preservation (which has nothing to do with preserving animals), corresponding to spaces that Heidegger would characterize as 'standing reserve.'. We use the term 'nature' or 'natural resources' to speak of as-yet undeveloped areas. Across the globe, east and west north and south, in North America as in South America, in Africa as in Europe, we demolish forests for farmland and furniture and if predator should wander down form the mountains, there is no question but that it will be killed either immediately by killing it or indirectly by displacing it, be it male or female, all as so much pest control and we regard such executions, such assassinations, as trivially justified. Survival of the fittest is not the triumph of the best form of life, but very tautologically - all of math and much of science depends on such tautologies - the triumph of those who happen to have survived.

The kind of thinking that smuggled a hierarchy of natures into evolution was a leftover from religious and indeed and from a different perspective of certain (if not all) aspects of Aristotelian ways of thought. Schopenhauer similarly concludes that "even Kant's basis for ethics" turns out to be "merely theological morals in disguise." 16 . And the problem with theological morals is only that these are not very moral ${ }^{17}$. One pursues one's good, be it in this life or the next but the pursuit is clearly about the self, which is to say that it has nothing to do with morality per se but salvation and that is one's highest good.

Schopenhauer charges that it is religious presumption that encourages us to strip animals of gender designations. Thus he points out that "in English all animals are of the neuter gender and so are represented by the pronoun 'it' just as if they were inanimate things ... it is

\footnotetext{
${ }^{15}$ I argue this point in connection with Heidegger's critique of technology in the last chapter of BABATTE, Babich. Words in Blood, Like Flowers: Philosophy and Poetry, Music and Eros in Hölderlin, Nietzsche, and Heidegger (Albany: State University of New York Press, 2006/2007).

16 SCHOPENHAUER, Arthur. On the Basis of Morality, p. 12o.ye

17 Theological morality is perfectly self-interested. A Spanish philosopher friend of mine, Antonio De Nicolás, a former Jesuit, enjoyed highlighting the paradoxical quality of the overweening egoism of the beautiful prayer Anima Christi. The point of the prayer, the point of all Judeao-Christian prayer, is to and for the advantage of the sufferer. Nietzsche would criticize this by pointing to the Christian's desire to be, as he said, "well-paid" (AC §45).
} 
unmistakably a priestly trick for the purpose of reducing animals to the level of things." 18 . Indeed, we neuter animals in word as we so commonly neuter them in deed in our everyday dealings with animals, castrating even the animals we like, namely our pets, with a perfect good conscience, just as human slaves were castrated for the same reasons by their human masters not too long ago in America and elsewhere in the world ${ }^{19}$. For Schopenhauer, when one reviews the range of "antimoral forces ... the problem ... of finding a motive that could induce man to take a line of conduct opposed to all those deeply ingrained tendencies of his nature ... is so difficult that, to solve it, it was everywhere necessary for the great majority of men to have recourse to the machinery from another world" ${ }^{20}$. This deus ex machina refers to compensation as a reward for right action. As Schopenhauer reflects, "A reward in another world firmly believed in is to be regarded as a perfectly safe investment, payable at a very long date" 21 . We can recall Nietzsche's similar indictment of Christianity (as indeed of Western religion, such as Judaism and Islam, as well), analyzing the Christian longing for an eternal reward as a desire "to be well-paid". For Nietzsche, today's slave-morality has learned to defer such desired compensation to the next generation, although by means of science and technology, we are hoping these days to collect just a little sooner. Thus for Schopenhauer, the economy of moral incentive in this equation eliminates the religious from consideration as an explanation of selflessness or non-egoism: How, he asks, "could I talk of unselfishness where I am enticed by reward or deterred by threatened punishment?"22. Consequently Schopenhauer will argue that solely "the absence of all egoistic motivation is ... the criterion for an action of moral worth." ${ }^{23}$. Fascinated as we are with ourselves, Schopenhauer goes so far as to argue that if we did take an overweening interest in ourselves as in fact we do, life would be unbearable. How he asks does it happen that we are nonetheless drawn, indeed spontaneously so, to help others? How can we explain kindness (what de Waal calls empathy and Schopenhauer names compassion) to

\footnotetext{
18 SCHOPENHAUER, Arthur. On the Basis of Morality, pp. 177. Schopenhauer refers to "the strange fact that in English, all animals are of the neuter gender and so represented by the pronoun 'it,' just as if they were inanimate things." Ibid., p. 176.

19 See SPIEGEL, Marjorie. The Dreaded Comparison: Human and Animal Slavery (New York: Mirror Books, 1997) and see too the first chapter of Patterson's Eternal Treblinka, cited below.

20 SCHOPENHAUER, Arthur. On the Basis of Morality, p. 137.

21 SCHOPENHAUER, Arthur. On the Basis of Morality, p. 137, cf. 142.

22 We note in passing here that both Nietzsche and Schopenhauer follow no one but Jesus in this line of argument, including the metaphor of compensation when he said "you have your reward".

23 SCHOPENHAUER, Arthur. On the Basis of Morality, p. 140.
} 
those we do not know, where such kindness does us no good? Kant suggests that such action has moral worth precisely when, to be sure of this, he says only when, it does us no good. By elimination, proving that it has no other value, the only value it can have is a moral one. But why should such actions exist in the first place? Upon seeing an injustice done to another we are often (not always but I will return to this later) moved to indignation, to longing for justice, that is: we want to intervene, we want to help. We are not moved to pity or sympathy alone but and this is what requires explanation we are spontaneously moved to act, to give up our own comfort and advantage, sometimes losing our lives in the process. Note that Schopenhauer is exactly not describing moral sentiment or a feeling but adverting to a phenomenon that can be found everywhere and at all levels of society.

Thus Schopenhauer argues for the supreme value of compassion, contending in an unmistakably Kantian voice (all of Schopenhauer is unmistakably Kantian and even when he proclaims his philosophy superior to Kant, it still sounds like a superiority of a Kantian kind): "only insofar as an action has sprung from compassion does it have moral value."

See someone stumble and we spontaneously reach out to help them-a spontaneity that is to the point of Schopenhauer's claim that compassion is an everyday phenomenon. The Canadian theologian and philosopher, Bernard Lonergan was not referring to Schopenhauer when he recounted his experience of seeing a little girl begin to fall while walking with her mother. The girl was some 20 feet away from him, so there was no chance of a direct intervention. What impressed Lonergan was the direct and physical and very active nature of his response and he emphasized the force with which he suddenly responded by reaching out, although he could not reach her, as if he could catch her. The gesture was pure intentionality. Lonergan had his own, good Thomistic explanation for this but it seems to me that what so struck him was nothing other than the immediacy (and improbable impulsiveness) of what Schopenhauer names "the great mystery of ethics." 24 . Compassion of this kind extends even beyond our direct capacity to help: we are moved by film and literature in this way and the letters we get asking us for contributions to so many very good causes also play on this same compassionate impulse.

\footnotetext{
${ }^{24}$ Schopenhauer elsewhere points out that if we did not take as extreme and overweening an interest in ourselves as we in fact do, that life would be unbearable.
} 
As Schopenhauer points out, compassion is spontaneous impulse, hence it is neither posited nor deduced nor indeed inferred in any inductive or other fashion. Like de Waals, Schopenhauer calls attention to empathy, Einfühlung, the feeling of sympathy for another's pain (for those moved to reduce the phenomenon of spontaneous compassion to so many mirror-neurons, Schopenhauer argues that we are not so moved to spontaneous action by the sight of another's enjoyment or pleasure). Hence, Schopenhauer argues if all motives, be they physical and metaphysical or religious, have as a result that "in some roundabout way, the real incentive is ultimately the doer's own well being and suffering," which means, consequently, that the action is effectively or ultimately "egoistic and so without moral worth" 25 only compassionate acts have moral worth properly speaking. In compassionate action, one "has in view simply and solely the weal and woe of someone else ... [one] has absolutely no object other that that the other man will be left unharmed, or will even receive help, assistance, and relief." 26.

Schopenhauer argues that it is only "possible for a suffering which is not mine and does not touch me to become just as directly a motive as only my own normally does, and to move me to action" to the extent that one feels the pain of the other "in, with and through him," and he emphasizes in so many words: we are in immediate communion, with-feeling, feeling-into the other in compassion: mitleid in this sence is mitsein. "although it is given to me merely as something external, merely by means of external intuitive perception or knowledge, I nevertheless feel it with him, feel it as my own, and yet not within me, but in another person." ${ }^{27}$. As Schopenhauer affirms, using Kantian rather than mystical language, this is a "mystery": that is, "it is something our reason can give no direct account of, and its grounds cannot be discovered on the path of experience." ${ }^{28}$. Nevertheless it is something that "happens everyday; everyone has often experienced it within himself; even to the most hardhearted and selfish, it is not unknown. Every day it comes before our eyes, in single acts on a small scale, wherever, on the spur of the moment, and without much reflection, one man helps another, hastens to the assistance of one whom he has seen for the first time, and in fact sometimes exposes even his own life to the most obvious danger for the sake of that man without thinking of anything except that he sees the

\footnotetext{
25 SCHOPENHAUER, Arthur. On the Basis of Morality, p. 143.

26 SCHOPENHAUER, Arthur. On the Basis of Morality, p. 143.

27 SCHOPENHAUER, Arthur. On the Basis of Morality, p. 165.

28 SCHOPENHAUER, Arthur. On the Basis of Morality, p. 166.
} 
other's great distress and danger." ${ }^{29}$. De Waal's example of an adult chimpanzee who drowned - chimpanzees do not swim, we are told—after jumping into a moat at a zoo to rescue an infant who had fallen in, illustrates such an impetus on behalf of another.

No sooner had Schopenhauer made his case for compassion than the mechanists of spirit, as one might call them, moved in to argue a contrary position based on blind habit and social mechanization or "reinforcement.". These are of course the English psychologists to whom Nietzsche alludes in the first section of On the Genealogy of Morals, naming Herbert Spencer and Paul Rée. Most of us will have heard of Spencer, it is likely that fewer of us will know Rée's work. ${ }^{30}$. Indeed, the task of identifying these "psychologists" (beyond Spencer and Rée) is a tricky one (made trickier by the persistence of suggestions made by well-meaning translators and editors and the relatively undisturbed penchant of source scholarship for ignoring even the caveats or limitations they themselves underscore) for what it inevitably presupposes is that we know what Nietzsche means by speaking of "psychologists" and that the authors that would strike us as significant today would be the same authors who struck Nietzsche or indeed his contemporaries (and these may be different) as noteworthy. What can be said, beyond all the problems of giving a name to these psychologists, Nietzsche's "old, cold, and tedious frogs," is that we have our contemporary correspondents for the same reductive role in the language of "selfish genes," language which can be extended to the rhetoric of neurobiology. According to these sociobiological/cum neuroscience accounts, altruism is solely to be seen as altruism on the individual level. Regarded from the level of the species, altruism turns out to be not altruism at all but egoism on a "higher" level, this is a sneaking Hegelianism, and the evolutionary socio/biologist or evolutionarily-minded philosopher argues that such deeds serve the proliferation of either our gene line or our mitochondria (passed down from pair to pair, and carrying the genetic legacy of each, in a struggle, male line and female line, persisting like Arjuna's warriors in the dynamic life of the dividing zygote). From such a perspective, inconvenient details, like Schopenhauer's reference to helping a person I have never seen before, can be conveniently ignored for it is, as it were, mitochondrion that calls

${ }^{29}$ SCHOPENHAUER, Arthur. On the Basis of Morality, p. 166.

${ }^{30}$ Rée's complete works are now available in German, edited by TREIBER, Hubert Treiber [Ed.]. Paul Rée: Gesammelte Werke, 1875-1885 (Berlin and New York: Walter de Gruyter Verlag, 2004) and see Robin Small's edition and translation of Paul Rée, SMALL, Robin. Basic Writings (Chicago: University of Illinois Press, 2003), including “The Origins of the Moral Sensations," pp. 85-167. 
to mitochondrion across the cells, across the individual and his or her genetic strain, and so across species boundaries. And if we can argue for nucleotides, we can argue for macromolecules, and so on.

We are thus so many collocations of systemic effects or reverberations of systems of molecules which have reasons, to invert Pascal, that the mind knows not of. The point for Nietzsche, and this is the point of departure for his On the Genealogy of Morals, is that this argument for morality is utterly ignoble, utterly unexcellent, without purity, without even the starry heaven above, to which very earth-bound celestial vision Nietzsche refers to in his Schopenhauer as Educator. This Nietzsche denounces as the real partie honteuse- the new scientific advocacy of the evolutionary basis of morality, already well advanced in Nietzsche's day by scientific tourists enlightening all of us as to the true basis of morality. To the extent that animals are mechanisms and inasmuch as we are like animals, we are reduced, as animals are, to the level of things.

We can argue for the evolutionary advantage of physical attributes, speaking of the upright stance characteristic of hominids, or we could have discussed the human eye or the brain and we can argue for the still insufficiently explained role of social attributes (some theorists, their imaginations frozen at the level of the gene, speak of memes using the only structural metaphor they know. Human beings are not born self-sufficient (this is, as you will recall, the weak point in the argument above) and we need instruction: culture does that for us. Hence where certain theorists speak of memes, Schopenhauer and Nietzsche speak of the perfection of ethics and in Nietzsche's case of the exemplary ideal of cultural excellence. Thereby the advantages gained in an individual life or cultivated throughout certain epochs can be transmitted to others. Evolution can thus account for human collective life, as it can also account for human violence and competition, as well as human cooperation. But is this enough? Does occasional cooperation, we all get together and cooperatively shake a fruit tree, or you help me gather fruit in some other way, as baboons do, who work together to turn over large rocks for all to share in the insects uncovered, or in the case of dolphins who cooperatively herd tuna, does such mutually enlightened selfand other-benefiting enterprise account for ethics? As philosophers have spoken of it (note that I here include those philosophers like Nietzsche who have polemicized against it), this notion of good is exactly advantageous: good for something or other: useful, beneficial, but 
not moral. Utilitarians have tried to turn this to their advantage by saying that the moral is what is useful and this is what we mean when we call something good but I find this a matter of turning a deficiency into a strength - the famous case of making lemonade when lemons are what you have. If the moral good is defined as self-interest, I need only follow my own interest when I help you, which is of course exactly in your interest and we conveniently luck out, except in the important and critical case where we are political enemies, for example if one us is a Nazi and the other a Jew or a gypsy or one of us is an Israeli and the other a Palestinian or a Lebanese. Cooperation on this basis is exactly convenient but it is limited to circumstances of un-conflicted mutuality and most importantly its benefit is not moral. From an evolutionary point of view, because helping others can, on the average, turn out to provide benefits, such as sharing in the fruit (or bugs!) gathered, maybe starting and cultivating a friendship (garnering good will for future favors), actions traditionally labeled moral can be explained in terms of evolutionary advantage and de Waal, as we have seen has discovered evidence for this in primates similar enough to those in ourselves so that we are off and running with the tacit program (this is not de Waal) that would eliminate the category of morality: all human and all animal action would be a matter of egoism. Kant (and Schopenhauer and Nietzsche) would of course have the same objections to evolutionary advantage as opposed to individual interest. I, for my own part, think that one can argue instead that moral behavior, that is, a genuine sense of justice and not just advantage, a true sense of empathy, and not just selfish calculation has evolved.

The counter claim here is that evolution can't explain morality if only because evolution is so very useful for explaining egoism. The evolutionary test is quintessentially egoistic: you (or your genes, for the evolutionist this is the same) pursue your own advantage. By contrast here, young people have the advantage of knowing full well that they in who they are, as those Nietzsche addresses in his Schopenhauer as Educator, can never be reduced to their genes if only because one's genes have nothing to say to the meditative examination Nietzsche poses, and every thoughtful young person understands this challenge, how can we find ourselves, how can we recover ourselves beneath all our masks, that is, beneath the imposition of society, beneath our so-called "memes", if one likes this metaphor, that is also to say, beneath all socially imposed mores or received 
morality: finding oneself beyond what one calls good, beyond the perturbations of the day and your environment. Thus Nietzsche writes (and this is a question of spiritual discernment), of coming to know oneself so as to be able to come to be the person that one is quite apart from all that is handed down or assigned to us. For the sake of such a meditation, Nietzsche writes, "Let the young soul look back on its life with the question: What have you up to now truly loved, what attracted your soul, what dominated it while simultaneously making it happy?" (SE §2) This is the thought experiment of thought experiments for Nietzsche means it as a modality of self-discovery and self-recovery. Following such a distinguishing identification of the things that move and so bring joy to the soul, Nietzsche advises:

Place this series of revered objects before you, and perhaps their nature and their sequence will reveal to you a law, the fundamental law of your authentic self. Compare these objects, observe how one completes, expands, surpasses, transfigures the others, how they form a stepladder on which until now you have climbed up to yourself; for your true being does not lie deeply hidden within you, but rather immeasurably high above you ... (Ibid.)

Find what moves you thus and you begin to find yourself.

\section{Becoming Moral, Becoming the One You Are}

When we talk of morality, we are talking about what we should or ought to do. It is another question for another day whether Nietzsche seeks the self down deep-in the genes as it were - or in the esoteric heights above us. Nietzsche's innovation is to ask us to ask, following Schopenhauer, who we are. He departs from Schopenhauer in that he suspects that the answer is complicated by 2000 years of the reign of monotheism, this is Western, very Western religion, a religious system that so far from coming to an end in the age of science has just begun a new lease on the domination of life and that for Nietzsche is a perfect and very stubborn antipathy to life (with all its suffering, with all its sickness and disappointments, life with its procreation which is to say the surpassing annulment of the individual in age and in death). If Schopenhauer is able to give us a universal maxim for actions of genuine moral worth, a supreme principle of ethics, Nietzsche reminds us that 
"we are unknown to ourselves, we men of knowledge" (GM §i) even as he repeats the schoolman's principle, that what we do follows from what we are, to dangerously different effect. $^{31}$ We dare not, Nietzsche writes in his preface to On the Genealogy of Morals, "make isolated errors or hit upon isolated truths. Rather do our ideas, our values, our yeas and nays, our ifs and buts, grow out of us with the necessity with which a tree bears fruit." (GM §ii). Nietzsche's question here, he tells us this himself, has to do with the worth of the judgment made regarding moral worth for Schopenhauer as for Kant and it would seem that here he poses his question almost in an evolutionary voice: "under what conditions did man devise these value judgments good and evil? And what value do they themselves possess?" (GM §v). In this spirit, Nietzsche calls for "a critique of moral values, the values of these values themselves must first be called in question ..." (GM §vi).

If Schopenhauer argued that Kant's "basis of ethics" turned out to be "merely theological morals in disguise" ${ }^{32}$ Nietzsche challenged the enlightened scientific "psychology" of his day, challenging the scientific and reasonable utility of utilitarian but also conventionally approbative theories but that also means evolutionary accounts of morality: "The utility of this unegoistic action is supposed to be the source of the approval accorded it, and this source is supposed to have been forgotten - but how is such forgetting possible? (GM I:3) Nietzsche continues "Has the advantage of such actions come to an end at some time or other? The opposite is the case: this advantage has rather been an everyday experience at all times, therefore something that has been underlined again and again: consequently, instead of fading from consciousness, instead of becoming easily forgotten, it must have been impressed on the consciousness more and more clearly." (Ibid.).

The problem then is not how to explain why human beings might be inclined to help one another and there are any number of theories that attempt to do this. The problem that remains is to explain why this inclination is moral. And that is what Kant seeks to do with his categorical imperative. Schopenhauer's moral philosophy opens up the space of scientific observation (this is not the same as pregiven or prescribed scientific theory) by citing Kant's demarcation of the limits of his practical philosophical reflections. Kant's

\footnotetext{
31 There is so much determinism in Nietzsche's phrasing of Schopenhauer's discussion of character which would for Nietzsche be a matter of "psychology" that some readers are convinced that Nietzsche is what they call a naturalist, but these are analytic readers as innocent of Schopenhauer's and Nietzsche's Kant (this is not Kuno Fischer's Kant, it is not Paul Guyer's Kant) as they are of the scholastics against whom of course most notably Kant should be read.

32 SCHOPENHAUER, Arthur. On the Basis of Morality, p. 120.
} 
special brilliance lay in the elegance with which he turned a limitation into an advantage: "“In a practical philosophy we are not concerned with stating reasons for what happens, but with giving laws as regards what ought to happen, even though it may never happen.",33 The ideal is the enemy of practical or real life. This, as clever children already know, means that what ought to happen is relegated to a realm nicely separate from what is done in practice.

Following Kant, what people happen to do is precisely irrelevant to practical philosophy. This irrelevance is an old trope-indeed a free pass - for the philosopher reflecting on the ideal society. In Plato's Politeia, when his interlocutors object that Socrates has depicted an ideal state that can never come about in reality, Socrates replies that such impracticality is irrelevant to the qualities of the practical or political philosophy he proposes just as the beauty of a statue is not diminished by being more beautiful than life, and Aristotle argues that his ideal of what a friend should be is not reduced by saying that a friendship of that kind has never existed. It is owing to this same perfectly sanguine lack of relevance or applicability in Kant's moral philosophy that Schopenhauer can declare that "Kant's $\pi \rho \omega \tau \sigma v \operatorname{v} \varphi \varepsilon v \delta o \zeta$ lies in his conception of ethics itself." 34 . For Schopenhauer, by contrast, ethics has to be about what people do.

Schopenhauer's radical idea lies in the contrary (albeit still Kantian) direction: "I must, therefore, give the teachers of ethics the paradoxical advice of first looking around a little at the lives of men." ${ }^{35}$. Indeed Schopenhauer continues to express his point in specific opposition to Kant, saying, "that the student of ethics as well as the philosopher generally must be content with the explanation and interpretation of what is given, and thus of what actually is or happens, in order to arrive at a comprehension of it..." ${ }^{.6}$.

Nietzsche takes up Schopenhauer's reflective emphasis when he writes "it seems to me as though Kant really penetrated and radically transformed very few people at all. To be sure," Nietzsche continues, "the work of this quiet scholar, as we can read everywhere, is said to have unleashed a revolution in all fields of intellectual inquiry, but I just can't believe that." (SE § 3). Yet, Nietzsche muses, in order to be affected by Kant in this way one needs first of all to be capable of grasping, as not everyone is, the revolutionary import

33 SCHOPENHAUER, Arthur. On the Basis of Morality, p. 52.

34 Ibid. $\$ 3$

35 SCHOPENHAUER, Arthur. On the Basis of Morality, p. 121.

36 SCHOPENHAUER, Arthur. On the Basis of Morality, p. 52. 
of Kant's arguments as Schopenhauerr had done, to be one of the "most active and noble spirits, those who could never endure living in a state of doubt, [who] would [thus] experience a shattering and despair of all truth on the manner of Heinrich von Kleist." (ibid.). Nietzsche goes on to cite Kleist's description of the effect of the Kantian revolution: "We cannot decide," Kleist writes in a letter to a friend, "whether what we call truth really is truth, or whether it only appears to us to be such. If the latter is the case, then the truth we collect here is nothing upon our death, and all our efforts to procure a possession that will follow us to the grave are in vain..." (Ibid.).

This passion moves Schopenhauer when he proposes as the one rule of compassion Neminem laede [Injure no one] which for Schopenhauer requires more than the pity Nietzsche excoriates. Schopenhauer's moral ideal of loving kindness, and that is, of course, the plain meaning of compassion: cause or make no one to suffer, Neminem laede, includes the corollary "imo omnes, quantum potes, juva" — much rather help everyone as much as you can. Compassion thus entails "the immediate participation independently of all ulterior considerations, primarily in the suffering of another, and thus in the prevention or elimination of it; for all satisfaction and all well-being and happiness consist in this." 37.

As Nietzsche explained earlier in "On the Use and Disadvantage of History for Life,"38 "Few people truly serve the truth, because only a few people possess the pure will to be just, and of these even fewer possess the strength to be just." (HL §6). When Nietzsche undertakes his "Schopenhauer as educator" he points to a series of difficulties in coming to know whether we have this rareness of character as well as the illusions and the obstacles that stand in the way of finding ourselves even when, perhaps especially when we have such a rare nature. For it is not easy to reflect on ourselves, and reflection (or meditation or observation) out of time, untimely reflection, is not a neutral affair: "How easy it is" thereby, Nietzsche says, "to do damage to yourself that no doctor can heal. And moreover, why should it be necessary, since everything - our friendships and enmities, our look and our handshake, our memory and what we forget, our books and our handwriting — bears witness to our being." (SE §2; emphasis added).

${ }^{37}$ SCHOPENHAUER, Arthur. On the Basis of Morality, p. 144.

${ }^{38}$ Nietzsche's Untimely Observations, mediations that focus in turn on David Strauss and the historical Life of Jesus, on History, on Schopenhauer, and on Wagner, or otherwise said, his reflections on theoretical religion, comparative or hermeneutico-socological history, on life-exemplars, and on musical culture, should always be read together and against one another. 
I turn now to a brief look at good and evil in f Nietzsche's On the Genealogy of Morals with particular reference to the question of animal vivisection and the significance of pain.

\section{Others Like and Unlike Ourselves: On the Drama of the Ladies and the Question of Pain}

Unlike Schopenhauer, Nietzsche for his part talks rather more about pain than he does about compassion and he famously rails against the slavely-moral or moraline effects of pity, even if Nietzsche himself, that is personally, was as compassionate as Schopenhauer in his own affective life. What matters, and what gets our attention is that one might compare Nietzsche to the Marquis de Sade or to Georges Bataille for the frequency with which Nietzsche has recourse to images of cruelty, indeed, and the parallel continues, often in salacious terms, especially in On the Genealogy of Morals. In an exactly provocative voice, Nietzsche reflects on the sense-perception of pain in distant, pre-historical eras as a matter of constitution and perspective. "Perhaps at the time," he writes,

pain did not hurt as much as it does today, at least a physician might draw this conclusion who has treated Negroes (taking these as representative of prehistoric humanity) for serious cases of internal inflammation; such inflammation would drive even the best organized European almost to despair ${ }^{39}$ — but in the case of Negroes this does not happen. (In fact, the curve of human capacity for pain seems to fall off relatively abruptly, once one passes the upper ten thousand or ten million of high culture [Übercultur]; and I have no doubt that in comparison with a single painful night undergone by one hysterical little cultured lady, the total suffering of all the animals questioned in the interests of scientific research by means of the knife simply does not enter into the balance (GM II '7).

\footnotetext{
39 Nietzsche had a personal acquaintance not only with such inflammation but was also preoccupied with the question of the social and outward manifestations of pain., I discuss this personal familiarity in the context of the grievous (and accidental) injury Nietzsche suffered during his military service together with the relation between this experience and Nietzsche's account of the human and cultural cost of war in his Human, All-too-Human, in my introduction, "Habermas, Nietzsche, and the Future of Critique: Irrationality, The Will to Power, and War" to BABETTE, Babich [Ed.]. Nietzsche, Habermas, and Critical Theory (Amherst, NY: Humanity Books, 2004), pp. 13B46. See in particular, pp. 20-23.
} 
This aphorism appears in the context of the second part of On the Genealogy of Morals, focusing on obligation and debt and guilt and beginning with questions of memory and punishment and selective breeding, promises and sovereignty. With his speculation that perhaps in the past "pain did not hurt as much as it does today," Nietzsche installs a specifically rhetorical, and calculatedly scientific distance to the claims he seeks to make, much as Weininger and Freud (and others whose names have been forgotten) could set up a reflection on sexual behaviour and culture without offending $19^{\text {th }}$ century mores, the same mores that still stand as our standard for moral virtue today. So too with his reference to the "upper ten thousand or ten million," for, so the rhetorical point here seems to suggest: what would a few zeros matter between men of science or the particular interests of "scientific research" and its passion for putting animals under the knife. Think of Japanese whaling ships that kill whales in the interests of science (ah, the culinary marketplace). In the process, Nietzsche alludes to Schopenhauer but also to Kant's influential juridical model of experimental scientific inquiry ${ }^{40}$.

The virtue of Nietzsche's sexist and insulting example of the Bildungsweibchen (that is, the cultivated or "cultured little lady" who might in our day correspond to a lady of standing in someone's idea of the Social Register), is that this nineteenth century invention can faint or sigh, beat her breast, and in general make enough fuss about it that one pays attention to her indisposition, even if only by way of the dismissive word "hysteria." In our interactions with one another, at any level of society, the same games continue whether we are male or female, old or young, in different, more contemporary guises. For both on the level of the one suffering and on the level of the one perceiving the manifest or apparent suffering of another, there is parity - and this is a very human kind of Einfühlung, anticipatory and interpretive, like Freud's joke about the Jew travelling to Kracow who meets an acquaintance and seeks to deflect the ordinary habit of misrepresentation. Both parties are aware of the problem of perception and communication, of dissimulation and

\footnotetext{
40 The insight that put natural philosophers or scientists "on the path of certain progress," for Immanuel Kant was the discovery "that reason only perceives that which it produces after its own design; that it must not be content to follow, as it were, in the leading-strings of nature, but must proceed in advance with principles of judgement according to unvarying laws, and compel nature to reply its questions. ... Reason must approach nature with the view, indeed, of receiving information from it, not, however, in the character of a pupil, who listens to all that his master chooses to tell him, but in that of a judge, who compels the witnesses to reply to those questions which he himself thinks fit to propose." Preface to the second edition, KANT, I. The Critique of Pure Reason, trans. Norman Kemp-Smith (London: Palgrave-Macmillan, 203).
} 
both parties are of the tendency to discount or dismiss such claims in order to avoid being duped, which is the common source of projection, as it is for the two travelers in Freud's joke, the one by the other.

We are clever animals and we know it and for this reason, we tend less in our everyday estimations of another person's pain to sympathize with than to dismiss the other, and so to downplay the intensity of the other's pain, and we do this even as we acknowledge a declared expression of pain with sympathy. We note it without altogether believing it, wondering if, perhaps, it is not quite so bad, if perhaps "one" [that is not we ourselves but the other] might be overdoing it. Because the other is well aware of this discounting, there arises a tendency to exaggeration sometimes indeed not to mislead but to persuade in spite of or just given the cultural drama of mutual suspicion (as Nietzsche emphasizes in Human, All-too-Human, I: §51) and this dynamic feeds the cultivated drama of headaches and the communication of social pains.

To review the further point regarding other races and other species, precisely on the Victorian continuum invocated by the deliberately denigrating reference made to the "hysterical, little cultured lady," driven as she is by nature, today in the form of what we call hormones (and which psychiatrists continue to name with reference to hysteria and the only organ that matters to science - as Simone de Beauvoir quotes this judgment "Tota mulier in utero," "woman is a womb"), Nietzsche's diminishing references to "Negroes" and animals only serves to extend the analogy. Women are assumed to be closer to 'nature' than men, as are blacks and other non-whites (note the implication here that blacks are not human, for the same is similarly suggested of women), and both women and non-white are assumed to be closer to animals, as indeed are Jews and others we do not like.

In this context of women and blacks and Jews and so many others, as lesser, as akin to animals, Heidegger's infamous comments about the "agricultural industry" take on a frightening banality, all-too appropriate in a context we normally overlook, as we recall the offensive parallel Heidegger sought to underline, as Emmanuel Levinas has rightly emphasized. But it is also key, as the historian Charles Patterson reminds us in his book, Eternal Treblinka, that Isaac Bashevis Singer independently presented a strikingly similar

${ }^{41}$ BEAUVOIR, Simone de. Second Sex, (New York: Random House, 1989 [1949]), p. ix. De Beauvoir's first chapter began with "The Data of Biology." For this same reason Knopf contracted with H.M. Parshley, a biologist, to prepare the translation. 
example, paralleling Heidegger's reflections in "The Letter Writer," a story reflecting on human and animal suffering. Seen from the animal's perspective, Singer writes, "all people are Nazis; for the animals it is an eternal Treblinka." ${ }^{42}$. Theodor Adorno likewise reminds us to take exactly the perspective we are inclined to disregard as beneath our consideration and to reflect on the danger inherent in the very idea of (human) "dignity," and (market) value or "worth" precisely in the moralizing terms we ascribe "to humanity over and against the market worth of things and animals." ${ }^{43}$. As Adorno further argues, "animals play for the idealist system virtually the same role as the Jews for fascism. ${ }^{\text {44 }}$. The point parallels the comparison Isaac Bashevis Singer makes in his short story, even if it must also be said that reading it convinces us without managing to persuade us to change our lives or our ways of relating to animals or indeed to others in the world. Indeed Adorno's point echoes the parallel Heidegger had sought to make with his reference to agribusiness and the manufacture of corpses in terms of the blockade that was the result of war. ${ }^{45}$

I have sought above to explore the question of '1how' human beings become moral in terms of the significance of ethics in the course of human evolution. Yet it should be evident that this theme, as given, already assumes human beings are (or can be) moral beings to begin with (we assume that the very fact that we can reflect on this question including the possibility of a negative response means at the very least that we have some some scruples about the legitimacy of such a question, yet simply having such scruples is enough to demonstrate morality) and the question we have explored assumes that ethics plays a role in human evolution. The second assumption is the more problematic one and not because it assumes the actuality of evolution but rather because rather than environmental pressure it assumes animal action as influential or as playing a role in development.

I have approached the question of evolution and ethics as a philosopher rather than an evolutionary ethicist or anthropological psychologist which means that rather than assuming the givenness of the moral becoming of the human being, I have undertaken to remind you that we must ask about the nature of morality per se. What counts as moral

\footnotetext{
42 The historian PATTERSON, Charles. Eternal Treblinka: Our Treatment of Animals and the Holocaust (New York: Lantern Books, 2002) borrows its title from Isaac Bashevis Singer's "The Letter Writer." For the quote, see p. 183.

43 ADORNO, Beethoven, p. 80.

44 Ibid.

45 See for contextual citation and further discussion.
} 
action? What does it mean to say that an action is moral or, and in other words, what does it mean to say that an action has moral worth or value? Outside of philosophy one tends to assume that such questions betray a self-evident state of affairs or at the very least that one knows what morality is when one sees it.

The current scientific establishment tells us, as it has for the last century, that moral behaviour is an evolutionary adaptation. We are, as it were, programmed to be moral or immoral and morality is more or less an artifact of the process of evolution. As we evolved to walk upright and to talk on cell-phones to disembodied voices, so too have we evolved moral sentiment. Morality may thus be suppose to serve the purpose of propagating the species: if it did not, so the assumption goes, we would have given up morality in favor of immorality. And the debate is a very old one for philosophy, going back indeed to Plato and Socrates and the ethical turn, as we might think of it, a turn away from thinking about the natural world, as the original philosophers or physiologoi did, to thinking about ourselves and our way of being with one another. Thinking about ethics, thought about morality is inherently political and social. And in Plato's dialogue about the polis, the question of justice is put in question from the moment it is first presented in what appear to be the terms of evolutionary advantage.

Are we moral beings in fact?

Does ethics indeed play a role in human evolution?

Primatologists argue that chimpanzees have a moral sense and as chimpanzees go, so the reasoning here, so do we. I am prepared to concede all of this and even to argue that chimpanzees are moral beings and that we too are moral beings as well yet Nietzsche makes it plain as does Schopenhauer indirectly, that we are the anti-moral animals par excellence. To say this is not to say that we are inauthentic or prone to lying but it is to say that we are violent, that we are thoughtless, and that we are cruel. It is not that we lie, not that we are violent, all this can be found in our primate relatives as well, but much rather it is the extreme to which we take our lies and violence and perhaps most of all in our excessive good conscience about what we do and the way we do it, this self-exonerating and self-justifying strategy means that we do not simply perpetrate human evil or méchançeté but that we protest or justify our innocence in the process. Kant had observed this already in his practical philosophy, we don't lie so much as we argue that lying is 
alright but it took Nietzsche to recognize the functionality of the anti-moral within morality itself.

\section{Referências}

BEAUVOIR, Simone de. Second Sex, (New York: Random House, 1989 [1949]).

BABETTE, Babich. "Adorno on Science and Nihilism, Animals, and Jews." Symposium: Canadian Journal of Continental Philosophy/Revue canadienne de philosophie continentale, Vol. 14, Nº 1, (2011).

BABETTE, Babich. “On the Analytic-Continental Divide in Philosophy: Nietzsche's Lying Truth, Heidegger's Speaking Language, and Philosophy," In: PRADO, C. G., [Ed.] $A$ House Divided: Comparing Analytic and Continental Philosophy (Amherst, NY: Humanity Books, 2003).

BABETTE, Babich [Ed.]. Nietzsche, Habermas, and Critical Theory (Amherst, NY: Humanity Books, 2004).

BABETTE, Babich. Words in Blood, Like Flowers: Philosophy and Poetry, Music and Eros in Hölderlin, Nietzsche, and Heidegger (Albany: State University of New York Press, 2006/2007).

BARTAL, Inbal Ben-Ami; DECETY, Jean; MASON, Peggy. "Empathy and Pro-Social Behavior in Rats," Science, Vol. 334, no. 6061 (9 December 2011): 1427-1430.

EISNITZ, Gail. Slaughterhouse: The Shocking Story of Greed, Neglect and Inhumane Treatment Inside the U.S. Meat Industry (Amherst, NY: Prometheus, 1997).

ERWIN, Dennis; STORY, Matt (Babich interviewed). "An Impoverishment of Philosophy," Purlieu: Philosophy and the University (2011): 37-71.

IMHOFF, Daniel [Ed.]. CAFO: The Tragedy of Industrial Animal Factories (Earth Aware Editions, 2010).

JONES, James H. Bad Blood: The Tuskegee Syphilis Experiment-A Tragedy of Race and Medicine (New York: Free Press, 1982 edition).

JOLY, Alison. "That, There Is Me," London Review of Books, Vol. 23, No. 18 (20 September 2001): 11-12.

KANT, Immanuel. The Critique of Pure Reason, trans. Norman Kemp-Smith (London: Palgrave-Macmillan, 203). 
KRIMSKY, Sheldon. Science in the Private Interest (Lanham. MD: Rowman and Littlefield, 2003).

MARKUS, Erik. Meat Market: Animals, Ethics, and Money (Brio Press, 2005).

PATTERSON, Charles. Eternal Treblinka: Our Treatment of Animals and the Holocaust (New York: Lantern Books, 2002).

REVERBY, Susan M. Examining Tuskegee: The Infamous Syphilis Study and Its Legacy (The University of North Carolina Press, 2009).

ROBERTS, Catherine. Science, Animals, and Evolution: Reflections on Some Unrealized Potentials of Biology and Medicine (Westport, CT: Greenwood, 1980).

SCHOPENHAUER, Arthur. On the Basis of Morality, trans. E.F. J. Payne (Providence/Oxford: Berghahn Books, 1995 [1965]), p. 111. Über die Grundlage der Moral, In: Schopenhauer, Werke in Einem Bande (Munich: Hanser, 1977).

SCULLY, Matthew. Dominion: The Power of Man, the Suffering of Animals, and the Call to Mercy (New York: St. Martin's Press, 2002).

SMALL, Robin. Basic Writings (Chicago: University of Illinois Press, 2003).

SPIEGEL, Marjorie. The Dreaded Comparison: Human and Animal Slavery (New York: Mirror Books, 1997).

TREIBER, Hubert Treiber [Ed.]. Paul Rée: Gesammelte Werke, 1875-1885 (Berlin and New York: Walter de Gruyter Verlag, 2004).

VISVANATHAN, Shiv. "On the Annals of the Laboratory State," In: NANDY, Ashis [Ed.] Science, Hegemony, and Violence: A Requiem for Modernity (Oxford: Oxford University Press, 1988), pp. 257-288.

WAAL, Frans de [Ed.]. Tree of Origin: What Primate Behaviour Can Tell Us about Human Social Evolution (Cambridge: Harvard University Press, 2001).

Primatologist (London: June 2001).

. The Ape and the Sushi Master: Cultural Reflections by a

WARRICK, Joby. "They Die Piece by Piece". In: "Overtaxed Plants, Humane Treatment of Cattle Is Often a Battle Lost” Washington Post, Apr 10, 2001.

WASHINGTON, Harriet. Medical Apartheid: The Dark History of Medical Experimentation on Black Americans from Colonial Times to the Present (New York: Anchor, 2008). 
BABICH, Babette

Recebido: 11/12/11

Received: 12/11/11

Aprovado: 10/01/12

Approved: 01/10/12 